\title{
The Effect of Covid-19 on Stock Market Performance: Evidence from ASEAN5
}

\author{
Abdikarim Bashir Jama ${ }^{1^{*}} \quad$ Sabri Nayan ${ }^{2}$ \\ 1.School of Economics, Finance and Banking(SEFB), COB, Universiti Utara Malaysia, Po Box 06010, Sintok, \\ Kedah, Malaysia \\ 2.School of Economics, Finance and Banking (SEFB), COB, Universiti Utara Malaysia, Box 06010, Sintok, \\ Kedah, Malaysia \\ *E-mail of the corresponding author:sabrinayan9899@hotmail.com
}

The research is financed by Ministry of Higher Education (MOHE) of Malaysia through Fundamental Research Grant Scheme (FRGS/1/2019SSO1/UUM/02/31/KOD S/O 14407)

\section{Abstract}

In this paper, we investigate the stock price performance of the Covid-19 pandemic. Utilizing daily Covid-19, exchange rate, and yield bond of ASEAN5 countries over the period June 16 to July 15, 2020. We employ the Hausman test to find a suitable model in our study, and it suggested the Random Effect Model as the appropriate technique. According to the result obtained total cases has a statistically significant negative influence on the stock price, while yield bond has a negative and statistically significant effect on the stock price. Contrarily, the exchange rate has a positive and significant influence on stock price performance. Therefore, it's necessary to carry future studies by using other macroeconomic variables to obtain reliable and robust findings that could have a substantial consequence on policymakers.

Keywords: Total Cases, Exchange Rate, Bond Yield, Stock Price, Panel Technique

DOI: $10.7176 / \mathrm{JESD} / 12-16-01$

Publication date:August $31^{\text {st }} 2021$

\subsection{Introduction}

Antiquity has observed various endemic diseases that have triggered numerous deaths to date. The Black Deceased "Plague Eruption" that resulted in the demises of 75-100 million persons amid 1347 and 1351, the Bleeding Fever that happened in Mexico in 1545-1548, the Cholera widespread among 1899 and 1923, the AIDS virus that early seemed in Cameroon in 1908, relentless severe respiratory syndrome (SARS) that were operative in Canada and Asia amid 2002 and 2003, Ebola and Swine Influenza are some of them. Covid-19 is a sort of outburst that paramount arose in Wuhan City, Hubei Province, in December 2019 for China (Estrada et. al., 2020). It has been avowed as a pandemic by the World Health Organization (WHO) on March 12, 2020. By way of March 26, 2020, due to this widespread, the deaths have surpassed 22.000, which has sustained to impact the entire universe. In accumulation to China, there have been serious intensifications in the numeral of cases and death, particularly in Iran and Italy. These enlargements were underway to impact social and cultural accomplishments around the globe. Due to the virus, worldwide flights amid various nations have been negated, and margin intersections with hazardous countries have been locked. The state of Spare has been affirmed in some states. Intruding education for a definite period or changing to the online course scheme is another instance of how Covid-19 distresses life, expressly in France, China, Japan, Iran, Turkey, Italy, and countless nations including ASEAN5 namely Malaysia, Thailand, Indonesia, Singapore, and Philippine. Further, it has been proclaimed that administrations or congress with extraordinary involvement have been suspended or negated in various countries.

Nevertheless, the confederation matches have been postponed in many European countries and across the world. The Coronavirus outbreak negatively impacts international trade as well as social and cultural life. Particularly tourism, trade-in merchandises, manufacture, and transport segments have underway to be negatively influenced by this widespread. Consequently, Moody's and Standard \& Poors credit rating organizations have dropped China's evolution estimate for 2020, Renault, Nissan, General Motors and Peugeot, Toyota, and Honda determined to discontinue manufacture in China. Several nations that import properties from China or have their goods mass-produced in China have decided to end these undertakings. In line with all these negative impacts, it appears unavoidable that stock markets, economic development, and exchange rates will also have a portion in these circumstances.

The Covid-19 also had a tremendous influence on ASEAN5 including Malaysia, Singapore, Thailand, Indonesia, and the Philippines which is our main focus in this study. Although ASEAN5 has engaged stepladders to alleviate the economic impairment of the coronavirus eruption, these will not counterbalance the escalating recessionary or credit threat for most segments. The ASEAN5 are negatively pretentious by piercing reductions in external trade flows, inactive commodity prices that heaviness on fiscal incomes of commodity exporters, and financial market unpredictability that can trigger capital expenditures. Moreover, Singapore and Malaysia have 
revealed two years of trade confrontations and a few months of a worldwide pandemic can demoralize a period of export reclamation. While those nation's that depend on both tourism and exports predominantly for Malaysia and Singapore must now manage with long-term economic discontent. Contrarily, the current guideline situation is that Indonesia and Philippine will agonize a gigantic growth tightening in the $2^{\text {nd }}$ quarter, for instance, the Indonesia shrinkage will mean a plummet from 5.0 percent in 2019 to 0.5 percent in 2020, while comparable statistics of the Philippine display 5.9 percent and 0.6 percent in 2019 and 2020 respectively.

Nevertheless, Covid-19 had a considerable effect on how individuals work and guzzle whereby some nations encouraging Small Medium Enterprise (SMEs) to familiarize themselves with this fluctuating environment via adaptation to electronic business and digitalization. While, most of the South-East Asian nations have scope for dynamic monetary and fiscal policies approximately all states eased their monetary policy postures by lowering their benchmark interest rates, dropping obligatory reserve ratio, venue up funds to enable lending to impacted companies, momentary deferments of loan principal and interest reimbursements, elimination of loan associated to the Covid-19 from the scheming of non-performing loan ratio or decreasing bank charges. Governments of the ASEAN5 enforced stringent local containment procedures including constraint of huge scale occasions, leisure, and restaurants as well as school cessations and lockdowns are having a harmful influence on economic activities. Also, the lockdown methods that characterized diverse scales and scope imposed by Malaysia, Philippine, and Thailand are slowing down the economic activities for definite subdivisions which is haven also an indirect impact on other sectors. Indeed, the below graph indicated the impact of Covid-19 represented by total cases and total death on the stock price performance of ASEAN5 countries.

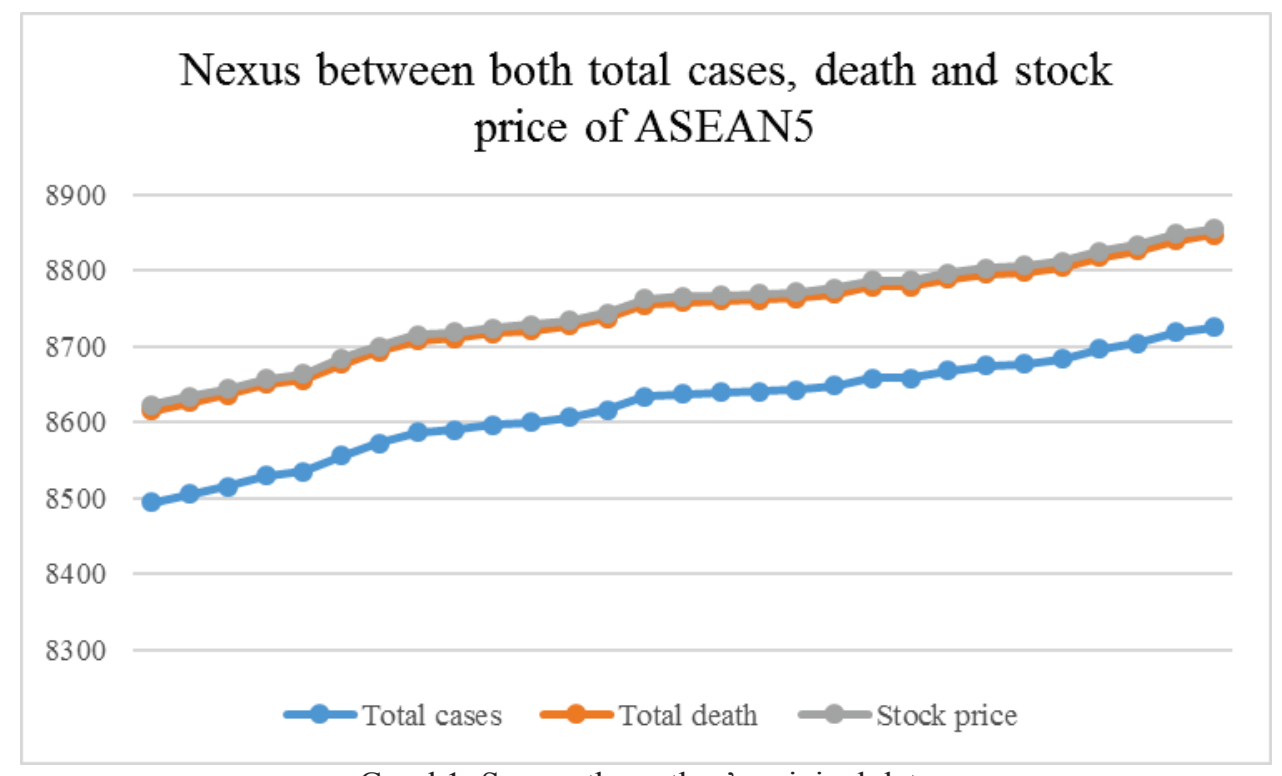

Graph1: Source the author's original data

The above table indicated that total cases, total death, and stock price move in the same direction, as we can observe the graph one. Since they move in the same direction it can be translated that they are cointegrated in the long run. However, the final result of their cointegration can only be approved by running a cointegration test. Therefore, from the above graph, we can perceive that these variables move in the same direction. Thus, the objective of this study is to investigate the impact of Covid-19 on the stock performance of ASEAN5.

The rest of the paper is designed as follows. Section 2 examines the literature on the nexus between Covid19 and financial markets. Section 3 exhibitions our econometric measurement, the data, and the appraisal procedures. Section 4 proposes valuation consequences and deliberation of these fallouts. Section 5 concludes and delivers policy implications.

\subsection{Nexus between COVID-19 and Stock markets}

Coronavirus had a tremendous influence on the financial market in general, particularly the stock market is significantly impacted during the shutdown period. Various studies found a positive relationship between Coronavirus and the financial market, for instance, the study made by Albulescu (2020) postulated COVID-19 and financial market volatility index in 40 days using a simple regression method. The result showed that merely fresh cases reported exterior China to have a positive influence on the volatility index, while the death ratio has a significant and positive influence on the volatility index for all tested models and the impact is robust for the death ratio outside China. Thus, the spread of coronavirus increases financial volatility. Similarly, Alam et al (2020) postulated Covid-19 and stock price using event study. Findings showed that the market responded 
positively with significant positive normal returns during the current lockdown period, and stockholders anticipated the lockdown and retorted positively.

According to Yousef (2020) postulated Covid-19 and stock market volatility employing simple regression and Garch model. The regression result revealed that Covid-19 as a dummy variable, the quantity of every day new cases, and the growth rate of daily new cases all had a significant positive impact on U.S stock market volatility. Moreover, based on Garch and other models that have been used revealed that the Coronavirus coefficient in the conditional modification equation has a significant positive influence on the restrictive variance for all three stock indexes. Therefore, it indicated that Coronavirus has augmented market volatility.

Furthermore, a study made by Gorsmen and Koijen (2020) examined Covid-19 and stock price. They found that the news about economic relief agendas in March appeared to have enlarged stock prices by decreasing risk antipathy and boost long term development expectation, however, did little to develop expectations about the short term. Moreover, a study made by Ding et al (2020) investigated Coronavirus and stock price. The result revealed that the corporations with robust pre-2020 financial circumstances accomplished superior stock price responses to Covid-19 than other comparable companies. Also, the firm's stronger corporate social responsibility (CSR) policies and accomplishments before the pandemic experienced greater stock price performance in reaction to the Coronavirus outbreak.

Contrarily, several studies reported a negative relationship between Covid-19 and the financial market, for example, Bahrini and Filfilan (2020), investigated Covid-19 and stock market returns employing panel data regression examination. The results revealed that the stock market in the Gulf Corporation Countries (GCC) responded negatively and with a great degree to new and total Covid-19 confirmed cases. Thus, during the outbreak daily returns of major stock market indices in the GCC nations declined as the number of confirmed death augmented. Al-awadhi et al (2020), examined the Covid-19 and stock market utilizing panel regression analysis. The outcome confirmed a significant negative influence of both daily growths in over-all inveterate cases and daily development in total deaths on the stock earnings across all firms in the Hang Seng index and Shanghai stock exchange during the pandemic epoch.

Similarly, a study made by Liu et al (2020), studied Covid-19 and the stock market, using the event study method. The result suggested that the Covid-19 outbreak had impacted negatively the stock market returns of all affected nations and areas. Moreover, findings indicated that the pandemic had a counter influence on main stock indices performance, with those Asia suffered a great decline in terms of abnormal returns. Ashraf (2020), investigated Coronavirus and stock market earnings, employing Pooled Ordinary Least Squares (OLS). Empirical findings showed that the stock market reacted robustly with negative incomes to evolution in the confirmed cases. Apergis and Nicholas (2020), postulated the Covid-19 and stock market using the Garch model. The result indicated that day-to-day escalations in aggregate confirmed Covid-19 cases in China, which are measured as total daily death and cases have a significant negative effect on the stock returns. Anha and Gan (2020), examined Covid-19 and stock market performance utilizing the panel data regression model. The study found that prior lockdown had a significant negative influence on Vietnam's stock market revenues. Further, the financial segment was the stiffest hit on Vietnam's stock market return throughout the epidemic period.

Nevertheless, a study made by Pagno et al (2020) postulated Covid-19 and the stock market using CAPM. The findings showed that the stocks of more pandemic resistant companies are forecasted to harvest significantly subordinate returns than less resilient ones, reflecting their inferior exposure to tragedy risk. Zeren and Hizarci (2020) postulated Covid-19 and stock markets employing the Maki Cointegration test. Based on the consequence attained from overall stock markets inspected with the entire death act together, in the long run, it has been discovered that over-all cases have a cointegration relationship with FTSE MIB, CAC40, and DAX30. Therefore, based on the above findings it is deliberated as one the finest possibilities for stockholders to circumvent investing in the stock markets and to turn invest in the Gold market, which saves investment harbor of each catastrophe period in the long run.

Nevertheless, Alber (2020), studied Covid-19 spread and stock markets utilizing the Generalized Method of Moment (GMM) model. The findings showed that stock market yield seemed to be sensitive to Covid-19 cases more than deaths and Covid-19 amassed indicators more than new ones. Moreover, the sturdiness analysis indorses the negative impact of the Covid-19 feast on stock market yield for Germany, China, Franca, and Spain, while these influences have not been established in the United State and Italy. Osagia et al (2020), investigated Covi-19 and the stock market using the Garch model. The outcome of the study exposed a forfeiture in stock earnings and extraordinary volatility in stock revenues under the Coronavirus era in Nigeria against the ordinary period underneath study. Also, after applying various Garch models with dummy variables the outcome of stock returns showed that Covid-19 had a negative influence on stock returns in Nigeria. Yilmazkuday (2020) investigated Covid-19 and S \& P 500 Index, using Vector Autoregressive Model. The empirical result showed having one percent of an escalation in aggregate day-to-day Coronavirus cases in the U.S resulted in about 0.01 percent of a cumulative decline in the S\&P 500 index after one day, and about 0.03 percent of a reduction prior one month. 
Finally, the study suggested that the negative impact of Covid-19 cases in the U.S on the S\&P 500 index has been observed in March. Equally, a study made by Senol and Zeren (2020) examined Covid-19 and Global markets using the Cointegration test. The empirical result indicated a long term association between the stock market and Covid-19. Also, the study found that epidemic diseases are found to impact the stock market negatively. Similarly, Heyden (2020) studied Covid-19 and Market reaction using Event study. The empirical result reported that stocks reacted negatively to the declaration of the first death in a given nation. The result also revealed that the announcement of country-particular fiscal policy procedures negatively impacted stock revenues and monetary policy procedures have the prospective to tranquil markets.

\subsection{Exchange Rate and Stock Market}

Many previous studies found mixed findings on the association between the exchange rate and the stock market. For instance, the study made by Ouma and Kihiu(2018) postulated exchange rate fluctuation and stock market performance from 2010 to 2015 using Cointegration, the Granger Causality Test, and Vector Error Correction Model (VECM). The outcome revealed the existence of both the short-run and the long-run affiliation between the exchange rate and stock market performance in Kenya. Khan and Ali (2015) studied the exchange rate and stock market returns from 1992-2013 utilizing Granger Causality and Garch model. The granger causality outcome indicated a bidirectional relationship between the exchange rate volatility and variability of the stock market price in Pakistan. Similarly, Olugbenga (2012) studied the exchange rate and stock market performance from 1985 to 2009 using the Johansen Cointegration test. Empirical findings indicated a significant positive stock market act to the exchange rate in the short run. Tian and Ma (2010) investigated the exchange rate and stock market employing Auto-Regressive Distributed Lag (ARDL). The findings showed the exchange rate affects stock prices and further observed a positive correlation between them. According to Pan et al (2007) postulated exchange rate and stock price from 1988-1998 employing Granger Causality and Vector Autoregressive Model. The outcome of the study revealed a substantial contributing relation from the exchange rate to the stock value for Malaysia, Japan, Hong Kong, and Thailand. While causal relation from the exchange rate to stock values is an institute in all countries apart from Malaysia.

On the other hand, many prior researchers found a negative link between the exchange rate and the stock market. To illustrate, a study made by Nordin et al (2020) postulated the exchange rate and stock market recital utilizing the Bound Testing approach. Empirical results of the study revealed that the exchange rate has a negative relationship with the stock price. Delgado et al (2018) examined the exchange rate and stock market from 1992 to 2017 using the Vector Auto-Regressive model. The result indicated that the exchange rate has a negative and statistically significant impact on the stock market, and this revealed that the indebtedness of the exchange rate is related to an increase in the stock index. Equally, Zubair and Aladejara (2017) investigated exchange rate volatility and stock market performance from 1986-2015 employing the Generalized AutoRegressive model. The result found no robust association between the stock market price and the exchange rate in Nigeria during the study period. Sichoongwe (2016) studied the exchange rate and stock price, and the findings revealed an inverse association between the exchange rate and stock price in Zambia. Suriani et al (2015) investigated the exchange rate and stock price from 2004-2009 employing the Augmented Dickey-Fuller test. Empirical findings showed demonstrated that no association exists between the exchange rate and stock price in Pakistan.

Similarly, the study made by Bekhet and Mugableh (2012) postulated the exchange rate and stock market performance from 1977-2012 employing the Bound testing approach. The study found a negative relationship between the exchange rate and the stock worth in the short and the long run in Malaysia. Maku and Atanda (2009) examined macro-economic variables and stock market performance from 1984-2007. The result revealed that the exchange rate has a long run significant negative influence on the stock market act. Likewise, Olowe and Ayodeji (2007) studied macro-economic variables and the stock market using Cointegration and VECM. The outcome of the study showed that the exchange rate harms the stock market performance in Nigeria. Kim (2003) examined the exchange rate stock price 1974-1998 employing the Johansen Cointegration test. The findings indicated that the stock price is negatively related to the exchange rate in the United States. Equally, a study made by Ibrahim and Yusoff (2001) postulated the exchange rate and stock worth utilizing the VectorAutoregressive model. The study observed the negative influences of depreciation shocks on the stock price in Malaysia.

\subsection{Yield Bond and Stock Price}

The relationship among changes in yields bond and stock prices has not been discussed widely in prior researchers since the term is closely related to each other. However, there are mixed findings whereby some studies demonstrated a simple negative association via the present value model. For instance, an intensification in forecasted future discount rates should result in both stock prices falling and long term interest rates to increase. Contrarily, a positive association is also possible due to movement in the long term interest rates that 
might be relevant to information about the upcoming dividend stream on stocks, Shiller and Beltratti (1992). Campbella and Ammer (1993) postulated the stock price and bond market. The empirical results revealed a positive, albeit low correlation between the stock and bond returns. Similarly, the study made by Anderson et al (2008) studied stock price and bond price from 1992 to 2006 using Dynamic Conditional Correlation. The outcome of the study revealed that the stock-bond correlation in sampling countries are positive most of the time, although a sustained period of negative correlation was reported during the study period. In contrast, Kim (2007) investigated stock price and bond yield utilizing the Wavelet Correlation investigation. The key empirical findings indicated that the correlation between alterations in stock prices and bond yields can differ from nation to nation. Also, based on wavelet analysis it indicated that changes in stock prices and bond yield have a negative correlation and don't move in the same direction.

Nevertheless, other studies showed the correlation between stock and bond return displays a considerable time difference, (Jones and Wilson, 2004; Cappiello et al, 2006; Connolly et al, 2005). Although bond and stock prices, in most cases tend to move in the same direction, current studies have also reported sustained periods of negative correlation.

\subsection{Methodology and Data}

The data utilized in this study were collected from two different sources. The data of total cases and total death as a proxy of Covid-19 was collected from https://github.com/owid/covid-19-data/tree/master/public/data, while data of stock price as a proxy for the stock performance was collected from the following site https://sg.finance.yahoo.com/quote/S68.SI/history/. This study uses a daily date from June16, to July 15, 2020. The pandemic outburst has been measured by Covid-19 cases and daily deaths. Further, it's measured by every day of the novel Coronavirus cases and fresh Corona deaths concerning the nation's populace. The study utilized several explanatory variables of daily data including exchange rate and yield bond. Furthermore, different prior researchers conducted a study using both total cases and death as a proxy for Covid-19 spread and stock price as a proxy for the stock performance namely: Alber (2020); Zeren and Hizarci(2020); Yousef (2020); Senoli and Zeren (2020); Ashraf(2020); Papadamou et al (2020).

Nevertheless, most of the studies that investigate the nexus between Coronavirus and stock market performance used an event study and different Garch techniques in their specific model. For instance, the study made by Liu et al (2020); Klose and Tillman (2020); Hyden (2020); Osagia et al (2020), and Yousef (2020). Contrarily, we adopt the panel data examination method over classical event study methodology due to different motives. Firstly, the feast of Coronavirus changes over a substance of days in the country and is not one point of time occasion. Secondly, panel data regression is superior in apprehending the time-difference association amid the dependent and independent variables (Ashraf 2017). Thirdly, panel data analysis excerpts both crosssectional and time-series dissimilarity from the underlying panel data and minimizing the problem such as multicollinearity, heteroscedasticity, and estimate partiality (Baltagi 2008; Woorldridge 2010). Also, the following studies used a panel data analysis namely: Klose and Tillmann (2020); Ashraf (2020); Nia (2020); Papadamou et al (2020).

Furthermore, before estimating the influence of Covid-19 on the stock price performance of ASEAN5 countries several econometric methods of testing are applied in this study. Firstly, the Hausman test is conducted to decide whether a fixed or random effect model is suitable for the dataset. The Hausman test is a statistical hypothesis test that assesses a more effective model against the less efficient one by checking the significance of an estimator versus an alternate estimator (Hausman, 1978). The test outcomes strongly suggest that the randomeffects model (REM) are suitable for the dataset because the probability is not significant and the null hypothesis is not rejected.

However, primarily, we specify the following model

$S T C P_{\text {it }}=\beta_{0}+\beta_{1} T C_{\text {it }}+\beta_{2} Y B_{\text {it }}+\beta_{3} X R_{\text {it }}+\varepsilon_{\text {it }}$

Whereby STCP represent the stock price of daily data

$\mathrm{BC}=$ Constant

$\mathrm{TC}=$ Total cases of daily data

$\mathrm{YB}=$ Yield bond of daily data

$\mathrm{XR}=$ Exchange rate of daily data

$\varepsilon_{\text {it }}=$ Error term of a country $\mathrm{i}$ on time $\mathrm{t}$

$i=$ Country

$t=$ Time Period 


\subsection{Results and Discussions}

Table 1. Variance inflation factor

\begin{tabular}{|l|l|l|l|}
\hline Variable name & Coefficient variance & Uncentred VIF & Centered VIF \\
\hline C & 195048.0 & 9.543112 & N/A \\
\hline Total cases & $7.44 \mathrm{E}-05$ & 2.653335 & 1.257547 \\
\hline Yield bond & 26925.69 & 19.04571 & 6.577866 \\
\hline Exchange rate & 0.004103 & 8.208295 & 6.546910 \\
\hline
\end{tabular}

The above table 1 displays variance inflation factor outcomes. Glauber and Farrar (1967) postulated that if the values are fewer than 10 percentage, it displays the deficiency of a multicollinearity problem between the independent variables. Therefore, there is no multicollinearity issue amid the independent variables of this study as we can observe the value of centered variance inflation factor. Indeed, a multicollinearity problem can reduce the accuracy of projected coefficients which deteriorates the statistical power of the regression model, and therefore could bias the outcome of our regression model. Therefore, it's necessary to carry out multicollinearity test detection before we proceed with other econometric tests in our panel data analysis.

Contrarily, before the discussion of the practical results, we recap the statistical tests to choose the most appropriate technique for the estimation of our econometric dimension. The test results are exhibited along with the estimates included in the control variables, offered in table 2.

Table 2. Regression fallouts of Random fixed effect model (RFEM)

\begin{tabular}{|l|l|l|l|l|}
\hline Variable & Coefficient & Std.error & T-statistics & P-value \\
\hline $\mathrm{C}$ & 2193.689 & 1728.311 & 1.269268 & 0.2064 \\
\hline Total cases & -0.005266 & 0.001214 & -4.338797 & $(0.0000)^{* * *}$ \\
\hline Exchange rate & 0.214806 & 0.052342 & 4.103871 & $(0.0001)^{* * *}$ \\
\hline Yield bond & -62.55472 & 36.83703 & -1.698148 & $(0.0916)^{*}$ \\
\hline $\mathrm{R}^{2}$ & 0.9997 & & & \\
\hline Observation & 150 & & & \\
\hline Hausam test & 0.8310 & & & \\
\hline Breusch and Pagan Lagrangian multiplier test & 0.0000 & & & \\
\hline
\end{tabular}

Table 2 consists total cases (TC), exchange rate (XR), yield bond (YB), and p-value are in parentheses: $\quad \mathbf{P}^{* * *}$ $<0.01, \mathrm{p}^{* *<0.05,} \mathrm{p}^{*<0.1}$

Formerly conferring the empirical results, we recap the statistical tests to select the most appropriate method for estimates of our econometric measurement. The test results are showed along with the estimations including the control variables, presented in table 2.

The Lagrangian multiplier test (LM) test is significant, and this indicates that the random effect model (REM) is statistically suitable than the fixed-effect model (FEM). Also, we performed the Hausman test to ensure the accuracy of the LM test, and to select the most suitable model in our study. The Hausman statistics are insignificant. Therefore, the random effect model is assumed to be more appropriate than the fixed-effect model.

Table 2 shows the various variables that influence the stock act of ASEAN5. We regressed the impact of each variable by guiding the other dominant elements that may influence stock performance, by utilizing the random effect model (REM). Moreover, to evaluate the impact of Covid-19 we use the number of total cases as a proxy, while the control variables were exchange rate and yield bond.

Our main interest at the moment is the effect of Covid-19 via using total daily total cases on the stock performance of ASEAN5. For instance, the total case is statistically significant and negative at the level of $1 \%$ indicating that one unit reduction in total daily cases will lead $-0.0053 \%$ unit increase in the stock performance. This is in line with findings of previous studies namely: Bahrini and Filfilan (2020); Al-awadhi et al (2020); Ashraf (2020); Apergis and Nicholas (2020); Alber (2020); Osagia et al (2020); Yilmazkuday (2020); Senol and Zeren (2020); Liu et al (2020), who found the Covid-19 has a negative and statistically significant effect on the stock performance of major stock markets. Accordingly. The number of new cases impacted all investors whereby hearing cases have a huge influence on the investor's mind. However, seeing that the stock markets of numerous countries do not perform according to the efficient market hypothesis but rather follow the behavioral finance theories. Therefore, investors in the stock market of ASEAN5 might be psychologically impacted if the number of death rates increased. Although, that the Coronavirus cases augmented day by day in ASEAN5 countries the death numbers were low compared to other countries, therefore it is understood that many investors preferred to invest in other save investment options including the gold market which can be seen as a reasonable choice for stakeholders. Also, with the growing feast of Covid-19, most commercial life moved toward the internet and it can extend for a while, therefore crypto-currencies such as Bitcoin can be seen as an alternative financial implement to devote. Further, to reduce the risk of turning to derivative merchandises will be one of the accurate possibilities. An alternative suitable investment possibility in this astonishing condition could be to 
move country markets where Coronavirus cases are comparatively low.

Contrarily, the control variable of the yield bond is statistically significant at the level of $10 \%$ and has a negative coefficient value of -62.5547 . This indicates that a one percent decrease in yield bond will result in a $62.5547 \%$ increase in the stock price, and line previous findings including Kim (2007). The negative association between the yield bond and stock price could be explained the high volatility to the great level of stock market instability that leads to a decoupling among these asset prices offering evidence for the imminent fight to a quality phenomenon (Anderson et al., 2008). However, regarding stock market instability depositors become more risk-averse and amend their portfolios from menace assets such as stocks to harmless assets such as longterm government bonds (Chang and Hsueh,2013; Durand et al., 2010; Cappiello et al., 2006; Thomadakis, 2012).

On the other hand, the second explanatory variable exchange rate is statistically significant at the level of $1 \%$ and positive coefficient 0.2148 , therefore one percent increase of exchange rate will lead $0.2148 \%$ increase in the stock price, and the outcome of this study is consistent the stock-oriented exchange rate model by Stavarek (2005) and the study made by Kutty (2010); Olugbenga (2012); Tian and Ma (2010), who institute a positive association among the exchange rate and stock price in short-run but not in the long run. While in the Asian context Kalimullah and Zulfiqar (2015) in their study found that exchange rate and stock price have a long-term association with each other in Pakistan. Overall, most of the previous studies found inconclusive outcome for the connection amid the exchange rate and stock value (Aggarwal, 2003; Roll 1992).

To sum up, our empirical results showed that all variables are statistically significant and have an effect on the stock price act of ASEAN5. Based on our regression outcomes it demonstrates that total case, yield bond, and exchange rate have an influence on the stock price during the study period.

\subsection{Conclusion and Policy Implications}

We can observe the coronavirus outburst that seemed in China toward the end of December 2019, has been documented as a pandemic by the World Health Organization (WHO) on March 12, 2020, after it feast to several countries. The virus had economic and social consequence whereby the social-cultural aspects has been limited, while country economics have been tremendously impacted the Covid-19 particularly the subdivisions such as trade, production, tourism, and transportation have encountered a huge challenge both domestic and international level.

Nevertheless, in this study, we investigated the affiliation between Covid-19 daily total cases with the stock market by using other explanatory variables including daily exchange rate and daily yield bond of Malaysia, Singapore, Thailand, Philippine, and Indonesia where Covid-19 has a huge impact. Moreover, our findings revealed that the stock market reacts negatively to the increasing in Covid-19 confirmed cases, thus the stock price decline as the number of cases enlarged in each country. Similarly, there is statistically a significant and negative relationship between the stock price and yield bond which shows the inverse relationship between the two variables during the pandemic period. However, the exchange rate variable showed a positive and statistically significant association with the stock price during the study period, and this could be attributed to the fluctuation of currency in ASEAN5 during the early stage of Covid-19. Indeed, our conclusions propose that stock market price in Covid-19 pandemic correlated risks in stock price early on when the number of inveterate cases rises.

Conversely, fallouts to be obtained at a wider incidence of date will express the potential effects of the epidemic on the financial market and economy with pure results, but most of the macroeconomic variables are measured annual, therefore, it's essential to include those variables in the future studies to have reliable results for policymakers.

\section{References}

Albulescu, C., 2020. Coronavirus and financial volatility: 40 days of fasting and fear. arXiv preprint arXiv:2003.04005.

Alber, N., 2020. The effect of coronavirus spread on stock markets: The case of the worst 6 countries. Available at SSRN 3578080.

Andersson, M., Krylova, E. and Vähämaa, S., 2008. Why does the correlation between stock and bond returns vary over time?. Applied Financial Economics, 18(2), pp.139-151.

Apergis, N. and Apergis, E., 2020. The role of Covid-19 for Chinese stock returns: evidence from a GARCHX model. Asia-Pacific Journal of Accounting \& Economics, pp.1-9.

Anh, D.L.T. and Gan, C., 2020. The impact of the COVID-19 lockdown on stock market performance: evidence from Vietnam. Journal of Economic Studies.

ALAM, M.N., ALAM, M.S. and CHAVALI, K., 2020. Stock market response during COVID-19 lockdown period in India: An event study. The Journal of Asian Finance, Economics, and Business, 7(7), pp.131-137.

Adenomon, M.O. and Maijamaa, B., 2020. On the Effects of COVID-19 outbreak on the Nigerian Stock Exchange performance: Evidence from GARCH Models. 
Ashraf, B.N., 2020. Stock markets' reaction to COVID-19: Cases or fatalities?. Research in International Business and Finance, 54, p.101249.

Ashraf, B.N., 2017. Political institutions and bank risk-taking behavior. Journal of Financial Stability, 29, pp.1335 .

Aggarwal, R., 2003. Exchange rates and stock prices: A study of the US capital markets under floating exchange rates.

Anderson, H.D., Malone, C.B. and Marshall, B.R., 2008. Investment returns under right-and left-wing governments in Australasia. Pacific-Basin Finance Journal, 16(3), pp.252-267.

Ashraf, B.N., 2021. Stock markets' reaction to COVID-19: Moderating role of national culture. Finance Research Letters, 41, p.101857.

Al-Awadhi, A.M., Alsaifi, K., Al-Awadhi, A. and Alhammadi, S., 2020. Journal of Behavioral and Experimental Finance.

Baltagi, B.H., 2008. Econometric analysis of panel data (Vol. 4). Chichester: John wiley \& sons.

Bahrini, R. and Filfilan, A., 2020. Impact of the novel coronavirus on stock market returns: evidence from GCC countries. Quantitative Finance and Economics, 4(4), pp.640-652.

Bhat, K.U. and Shah, S.Z.A., 2015. Empirical investigation of the relationship between exchange rate movements and Stock market volatility in the context of Pakistan. Pakistan Business Review, 814.

Bekhet, H.A. and Mugableh, M.I., 2012. Investigating equilibrium relationship between macroeconomic variables and Malaysian stock market index through bounds tests approach. International Journal of Economics and finance, 4(10), pp.69-81.

Connolly, R., Stivers, C. and Sun, L., 2005. Stock market uncertainty and the stock-bond return relation. Journal of Financial and Quantitative Analysis, 40(1), pp.161-194.

Chang, C.L. and Hsueh, P.L., 2013. An investigation of the flight-to-quality effect: evidence from Asia-Pacific countries. Emerging Markets Finance and Trade, 49(sup4), pp.53-69.

Cappiello, L., Engle, R.F. and Sheppard, K., 2006. Asymmetric dynamics in the correlations of global equity and bond returns. Journal of Financial econometrics, 4(4), pp.537-572.

Campbell, J.Y. and Ammer, J., 1993. What moves the stock and bond markets? A variance decomposition for long - term asset returns. The journal of finance, 48(1), pp.3-37.

Durand, R.B., Junker, M. and Szimayer, A., 2010. The flight - to - quality effect: a copula - based analysis. Accounting \& Finance, 50(2), pp.281-299.

Ding, W., Levine, R., Lin, C. and Xie, W., 2020. Corporate immunity to the COVID-19 pandemic (No. w27055). National Bureau of Economic Research.

Delgado, N.A.B., Delgado, E.B. and Saucedo, E., 2018. The relationship between oil prices, the stock market and the exchange rate: Evidence from Mexico. The North American Journal of Economics and Finance, 45, pp.266-275.

Farrar, D.E. and Glauber, R.R., 1967. Multicollinearity in regression analysis: the problem revisited. The Review of Economic and Statistics, pp.92-107.

Ghinai, I., McPherson, T.D., Hunter, J.C., Kirking, H.L., Christiansen, D., Joshi, K., Rubin, R., Morales-Estrada, S., Black, S.R., Pacilli, M. and Fricchione, M.J., 2020. First known person-to-person transmission of severe acute respiratory syndrome coronavirus 2 (SARS-CoV-2) in the USA. The Lancet, 395(10230), pp.11371144.

Gormsen, N.J. and Koijen, R.S., 2020. Coronavirus: Impact on stock prices and growth expectations. The Review of Asset Pricing Studies, 10(4), pp.574-597.

Heyden, K.J. and Heyden, T., 2020. Market reactions to the arrival and containment of COVID-19: an event study. Finance research letters, 38, p.101745.

Hausman, J.A., 1978. Specification tests in econometrics. Econometrica: Journal of the econometric society, pp.1251-1271.

Ibrahim, M.H. and Yusoff, S.W., 2001. Macroeconomic variables, exchange rate and stock price: A Malaysian perspective. International Journal of Economics, Management and Accounting, 9(2).

Jones, C.P. and Wilson, J.W., 2004. The changing nature of stock and bond volatility. Financial Analysts Journal, 60(1), pp.100-113.

Khan, R.E.A. and Ali, R., 2015. Causality analysis of volatility in exchange rate and stock market prices: A case study of Pakistan. Asian Economic and Financial Review, 5(5), pp.805-815.

Kutty, G., 2010. THE RELATIONSHIP BETWEEN EXCHANGE RATES AND STOCK PRICES: THE CASE OF MEXICO. North American Journal of Finance \& Banking Research, 4(4).

Klose, J. and Tillmann, P., 2020. COVID-19 and financial markets: A panel analysis for European countries.(202025).

Kim, S. and In, F., 2007. On the relationship between changes in stock prices and bond yields in the G7 countries: Wavelet analysis. Journal of International Financial Markets, Institutions and Money, 17(2), 
pp.167-179.

Kim, K.H., 2003. Dollar exchange rate and stock price: evidence from multivariate cointegration and error correction model. Review of Financial economics, 12(3), pp.301-313.

Liu, H., Manzoor, A., Wang, C., Zhang, L. and Manzoor, Z., 2020. The COVID-19 outbreak and affected countries stock markets response. International Journal of Environmental Research and Public Health, 17(8), p.2800.

Maku, O.E. and Atanda, A.A., 2009. Does Macroeconomic Indicators Exert Shock on the Nigerian Capital Market?

Nia, V.M., 2020. The effect of Corona outbreak on the Indonesian stock market. American Journal of Humanities and Social Sciences Research, 4(3), pp.358-370.

Nordin, N., Nordin, S. and Ismail, R., 2014. The impact of commodity prices, interest rate and exchange rate on stock market performance: An empirical analysis from Malaysia. Malaysian Management Journal, 18, pp.39-52.

Ouma, D.O. and Kihiu, E., 2018. Exchange rate fluctuations and stock market performance in Nairobi securities exchange, Kenya. Journal of Emerging Issues in Economics, Finance, and Banking, 7(1), pp.2434-2451.

Olugbenga, A.A., 2012. Exchange rate volatility and stock market behaviour: The Nigerian experience. European Journal of Business and Management, 4(5).

Olowe, R.A., 2007. The relationship between stock prices and macroeconomic factors in the Nigerian stock market. African Review of Money Finance and Banking, pp.79-98.

Papadamou, S., Fassas, A., Kenourgios, D. and Dimitriou, D., 2020. Direct and indirect effects of COVID-19 pandemic on implied stock market volatility: Evidence from panel data analysis.

Pan, M.S., Fok, R.C.W. and Liu, Y.A., 2007. Dynamic linkages between exchange rates and stock prices: Evidence from East Asian markets. International Review of Economics \& Finance, 16(4), pp.503-520.

Pagano, M., Wagner, C. and Zechner, J., 2020. Disaster resilience and asset prices.

Roll, R., 1992. Industrial structure and the comparative behavior of international stock market indices. The Journal of Finance, 47(1), pp.3-41.

Şenol, Z. and ZEREN, F., 2020. Coronavirus (COVID-19) and stock markets: The effects of the pandemic on the global economy. Avrasya Sosyal ve Ekonomi Araștırmaları Dergisi, 7(4), pp.1-16.

Stavarek, D., 2005. Stock prices and exchange rates in the EU and the United States: evidence on their mutual interactions. Czech Journal of Economics and Finance (Finance a uver), 55(3-4), pp.141-161.

Suriani, S., Kumar, M.D., Jamil, F. and Muneer, S., 2015. Impact of exchange rate on stock market. International Journal of Economics and Financial Issues, 5(1S).

Sichoongwe, K., 2016. Effects of exchange rate volatility on the stock market: The Zambian experience. Journal of Economics and Sustainable Development, 7(4).

Shiller, R.J. and Beltratti, A.E., 1992. Stock prices and bond yields: Can their comovements be explained in terms of present value models? Journal of Monetary Economics, 30(1), pp.25-46.

Thomadakis, A., 2012. Contagion or flight-to-quality phenomena in stock and bond returns. School of Economics Discussion Paper, (0612).

Tian, G.G. and Ma, S., 2010. The relationship between stock returns and the foreign exchange rate: the ARDL approach. Journal of the Asia Pacific economy, 15(4), pp.490-508.

Wooldridge, J.M., 2010. Econometric analysis of cross section and panel data. MIT press.

Yousef, I., 2020. Spillover of COVID-19: Impact on stock market volatility. International Journal of Psychosocial Rehabilitation, 24(06), pp.18069-18081.

Yilmazkuday, H., 2020. COVID-19 effects on the S\&P 500 index. Available at SSRN 3555433.

Zeren, F. and HIZARCI, A., 2020. The impact of COVID-19 coronavirus on stock markets: evidence from selected countries. Muhasebe ve Finans Incelemeleri Dergisi, 3(1), pp.78-84.

Zubair, Z.A. and Aladejare, S.A., 2017. Exchange rate volatility and stock market performance in Nigeria. Asian Journal of Multidisciplinary Studies, 5(11), pp.194-201. 